\title{
Diabetic pneumopathy: A study of induced sputum and pulmonary function in patients with type 2 diabetes mellitus
}

\author{
Rogério M. Bártholo, ${ }_{1}^{1}$ Elizabeth Bessa, ${ }^{1}$ Thiago P. Bártholo, ${ }^{1}$ Cláudia Henrique da Costa, ${ }^{1}$ Agnaldo José \\ Lopes, ${ }^{1}$ Rogério Rufino ${ }^{1 *}$
}

\begin{abstract}
Objective: To evaluate the cellularity, and albumin and interleukin (IL)-1 levels in induced sputum (IS), and to determine respiratory function parameters in patients with type 2 diabetes mellitus (DM2). Design: A cross-section study in type 2 diabetes mellitus. Participants: Patients with type 2 diabetes mellitus and healthy people. Methods: Patients in both groups had normal chest x-ray findings. Exclusion criteria for both groups were: the presence of current pulmonary disease or sequelae, smoking, respiratory atopy, or respiratory infection in the past 3 months. The study consisted of two sub-studies. In sub-study 1(SS1), measurements of pulmonary volume and flow, and diffusion capacity for carbon monoxide ( $\mathrm{DL}_{\mathrm{CO}}$ ) were performed. In sub-study 2 (SS2), analysis of cellularity, albumin, and IL-1 in IS was performed. Results: In all, 60 patients ( 45 women, $75 \%$ ) with DM2 with a mean age of 59.52 years (SD, 9.03) were included in SS1. The DM2 group included 8 patients with airway obstruction (13.33\%) without reversibility with bronchodilators, and 9 with restrictive disease (15.00\%) (p = 0.026). The $\mathrm{DL}_{\mathrm{co}}$ was reduced in 17 patients $(28.33 \%)$ in the DM2 group. In the control group, all individuals had values within the reference intervals. Lymphocytosis was found in the IS of patients with DM2 ( $\mathrm{p}=0.028$ ). The levels of sputum albumin showed no statistical difference between the two groups. Conclusion: Our findings indicate the presence of pulmonary impairment in DM2, characterized by changes in the respiratory function and a lymphocytosis in IS.
\end{abstract}

Keywords: Diabetes mellitus type 2; Induced sputum; Lymphocytes.

\section{Resumo}

Pneumopatia diabética: um estudo de escarro induzido e função pulmonar em pacientes com diabetes mellitus tipo 2

Objetivo: Avaliar a celularidade, os níveis de albumina e interleucina (IL) -1 no escarro induzido (EI) e determinar parâmetros da função respiratória em pacientes com diabetes mellitus tipo 2(DM2). Métodos: Estudo transversal e descritivo em pacientes com DM2 e grupo controle. Os pacientes de ambos os grupos apresentavam achados radiográficos normais no tórax. Os critérios de exclusão para ambos os grupos foram: presença de doença pulmonar ou sequelas atuais, tabagismo, atopia respiratória ou infecção respiratória nos últimos 3 meses. O estudo consistiu em dois subestudos. No subestudo 1 (SS1), foram realizadas medidas de volume e fluxo pulmonar e capacidade de
1. Thoracic Disease Department. Medical Sciences Faculty. Rio de Janeiro State University. Rio de Janeiro, Brazil.

*Correspondence address:

Rio de Janeiro State University - Thoracic Disease Department Av. 28 de Setembro, 72

Rio de Janeiro, Brazil.

ZIP 22261-020

BJHBS, Rio de Janeiro, 2019;18(2):144-150

Received on 06/09/2019. Approved on 09/29/2019.

difusão de monóxido de carbono ( $\mathrm{DL}_{\mathrm{Co}}$ ). No subestudo 2 (SS2), foi realizada análise da celularidade, albumina e IL-1 no EI. Resultado: Ao todo, 60 pacientes ( 45 mulheres, $75 \%$ ) com DM2 com média de idade de 59,52 anos (DP, 9,03) foram incluídos no SS1. O grupo DM2 incluiu 8 pacientes com obstrução das vias aéreas (13,33\%) sem reversibilidade com broncodilatadores e 9 com doença restritiva $(15,00 \%)(p=0,026)$. A DLco foi reduzida em 17 pacientes (28,33\%) no grupo DM2. No grupo controle, todos os indivíduos apresentaram valores dentro dos intervalos de referência. Linfocitose foi encontrada no EI dos pacientes com DM2 ( $\mathrm{p}=0,028$ ). Os níveis de albumina sérica e IL-1 não mostraram diferença estatística entre os dois grupos. Conclusão: Os achados indicam a presença de comprometimento pulmonar no DM2, caracterizado por alterações na função respiratória e linfocitose no EI.

Descritores: Diabetes mellitus tipo 2; Escarro induzido; Linfócitos.

\section{Resumen}

Neumopatía diabética: un estudio del esputo inducido y la función pulmonar en pacientes con diabetes mellitus tipo 2

Objetivo: evaluar la celularidad y los niveles de albúmina e interleucina (IL) -1 en el esputo inducido (IS) y determinar los parámetros de la función respiratoria en pacientes con diabetes mellitus tipo 2 (DM2). Métodos: Este fue un estudio transversal y descriptivo en pacientes con DM2 y un grupo de control.Los pacientes en ambos grupos tuvieron hallazgos radiográficos de tórax normales. Los criterios de exclusión para 
ambos grupos fueron: la presencia de enfermedad pulmonar actual o secuelas, tabaquismo, atopia respiratoria o infección respiratoria en los últimos 3 meses. El estudio consistió en dos subestudios. En el subestudio 1 (SS1), se realizaron mediciones del volumen y el flujo pulmonar y la capacidad de difusión del monóxido de carbono ( $\mathrm{DL}_{\mathrm{CO}}$ ). En el subestudio 2 (SS2), se realizó un análisis de celularidad, albúmina e IL-1 en IS. Resultado: En total, 60 pacientes ( 45 mujeres, $75 \%$ ) con DM2 con una edad media de 59,52 años (SD, 9,03) se incluyeron en SS1. El grupo DM2 incluyó 8 pacientes con obstrucción de las vías respiratorias (13,33\%) sin reversibilidad con broncodilatadores

\section{Introduction}

In 2000, the World Health Organization estimated that there were 171 million diabetics in the world and that this number would increase to 366 million in 2030. The American Diabetes Association estimates that in 2020, 192 billion dollars will be spent on the treatment of diabetes, as well as associated renal, cardiac, vascular and ophthalmic complications. This could represent up to $10 \%$ of the health budget in some countries. Diabetes mellitus (DM) is a growing public health problem, especially in developing countries ${ }^{2}$. In Brazil, estimates indicate that $6.4 \%$ of the population in the 17- to 79-year-old age group has type 1 or 2 diabetes, which includes more than 12 million diabetics ${ }^{3}$. The number of patients with DM is growing in Brazil. Around 90 to $95 \%$ of the patients are type 2 diabetics. In a study conducted in 5,301 municipalities that surveyed more than 22 million people, 3.5 million (15.7\%) tested positive for diabetes 4 .

Pulmonary complications in diabetic patients are due to vascular damage, which has a central role in the pathophysiology of diabetics. Despite the presence of a large capillary network in the lungs, pulmonary complications often go unnoticed. This is mainly because the alveolar capillary system is characterized by large microvascular reserves; therefore, pulmonary abnormalities are commonly subclinical in diabetic patients. However, the loss of microvascular reserves in the lungs, with an increased risk of hypoxia, may become clinically important in cases of acute or chronic pathological conditions, including pneumonia, chronic obstructive pulmonary disease (COPD), and asthma or fluid overload secondary to heart failure ${ }^{5,6}$.

DM is characterized by persistent hyperglycemia and abnormal metabolism of carbohydrates, proteins and lipids. These metabolic changes result from changes in the secretion of insulin, tissue sensitivity to insulin, y 9 con enfermedad restrictiva $(15,00 \%)(p=0,026)$. La DLCo se redujo en 17 pacientes (28,33\%) en el grupo de DM2. En el grupo de control, todos los individuos tenían valores dentro de los intervalos de referencia. Se encontró linfocitosis en el IS de pacientes con DM2 ( $\mathrm{p}=0.028)$. Los niveles de albúmina sérica e IL-1 no mostraron diferencias estadísticas entre los dos grupos. Conclusión: los hallazgos indican la presencia de insuficiencia pulmonar en la DM2 caracterizada por cambios en la función respiratoria y una linfocitosis en la EI.

Palabras clave: Diabetes mellitus tipo 2; Esputo inducido; Linfócitos.

or the coexistence of both mechanisms ${ }^{7}$. Little is known about the influence of diabetic microangiopathy on pulmonary function ${ }^{7}$. We evaluated the cellularity, and albumin level in induced sputum (IS), and determined respiratory function parameters in patients with type 2 diabetes mellitus (DM2) in order to characterize their diabetic pneumopathy.

\section{Methods}

This was a cross-sectional, descriptive study in patients with DM2 and healthy controls. The subjects underwent respiratory function tests that measured the diffusing capacity for carbon monoxide $\left(\mathrm{DL}_{\mathrm{CO}}\right)$ and pulmonary volume and flow, in addition to the collection of samples from the lower airways by sputum induction. The subjects underwent respiratory pulmonary function tests and, on another day of the same week, sputum induction was performed. The patients with DM2 were selected from a database of the Diabetes Service.

The study was approved by the Research Ethics Committee, number 2681/2011. All individuals who participated in the study provided written and informed consent.

\section{Characterization of the Groups}

Inclusion criteria for the DM2 group: Diagnosis of DM2 according to the criteria of the American Diabetes Association ${ }^{8}$, absence of current or residual pulmonary disease, absence of respiratory and skin atopy, absence of a current or past history of smoking, absence of respiratory infection in the past 3 months and normal chest radiographic findings. All patients were in regular monitoring for at least 6 months and were under glycemic control. All patients were using metformin, glibenclamide, a combination of the two, or insulin 


\section{Original article}

NPH and almost all of them used simvastatin, following medical advice. These medications are supplied for free by the Brazilian Ministry of Health.

Inclusion criteria for the control group: Healthy subjects with no history of dysglycemia and skin and respiratory atopy, absence of current or a history of smoking, and absence of respiratory infection in the past 3 months. All patients underwent blood glucose level assessment and chest $\mathrm{x}$-rays, which had to be normal for an individual to be included in the study.

\section{Exams}

Spirometry, static pulmonary volumes using the helium dilution, and $\mathrm{DL}_{\mathrm{CO}}$ measurements were performed using a Collins Plus Pulmonary Function Testing Systems appliance (Warren E. Collins, Inc., Braintree, MA, USA). All tests were performed as formulated by the American Thoracic Society ${ }^{9}$. The forced vital capacity (FVC), forced expiratory volume in $1 \mathrm{~s}\left(\mathrm{FEV}_{1}\right)$, total lung capacity (TLC), residual volume (RV), and DL $\mathrm{CO}_{\mathrm{C}}$ were measured. The bronchodilator response was identified based on the presence of a $12 \%$ variation and $200 \mathrm{~mL}$ volume in $\mathrm{FEV}_{1}$ and FVC after the use of $400 \mu \mathrm{g}$ of salbutamol. Airway obstruction was defined as $\mathrm{FEV}_{1} / \mathrm{FVC}<70 \%$ of the predicted ${ }^{9}$. The restrictive pattern was defined as the presence of TLC $<80 \%$ of the predicted. The cut-off points to define abnormal diffusing capacity was $<80 \%$ or $>120 \%$ of that predicted ${ }^{10}$.

Sputum induction was performed by a modified Pin method ${ }^{11}$. The patients inhaled $200 \mu \mathrm{g}$ of salbutamol to inhibit the constriction of airways and, 15 minutes later, inhaled an aerosol of hypertonic saline from a Pulmosonic Star ultrasonic nebulizer. The concentrations of saline solutions employed for 3 consecutive periods of 7 minutes each were 3\%, 4\%, and $5 \%$, respectively. The patients were requested to perform oral hygiene and rinse their mouths, gargle, and swish and swallow the water to reduce contamination from the contents of postnasal drip and saliva. The peak expiratory flow (PEF) was measured and repeated every 7 minutes or, if the patient mentioned discomfort at any moment, early monitoring for a potential bronchospasm was performed. The patient was asked to cough and expectorate into a sterile vial. If a $\geq 10 \%$ fall in PEF occurred, inhalation was stopped to prevent worsening of the bronchospasm. After the material was processed, slides were prepared for performing the differential cell count. Trypan blue and Diff-Quick staining were used to determine cell viability.
The level of albumin in the supernatant of induced sputum (IS) was measured by an enzyme-linked immunosorbent assay (ELISA) kit for albumin (Life Science Inc., USA) $)^{12}$.

\section{Statistics}

The sample size was determined as 60 patients, which has a 95\% ability to detect the difference between the averages 6.64 with a statistical significance $\alpha$ of 0.05 (two-tailed). The sampling was performed by convenience for the DM2 and healthy subjects. The ratio of diabetic patients to healthy individuals was 3:1. The quantitative data were expressed as means and standard deviations. Categorical variables were described using relative values and expressed as a percentage. Comparison between the anthropometric data, albumin, IL-1, cellularity of IS, FVC (\%), FEV 1 (\%), TLC (\%), and DL $\mathrm{DO}_{\mathrm{CO}}(\%)$ was performed using variance analysis (ANOVA). The frequency of individuals who had changes in pulmonary function was measured by the chi-squared test. The analyses were performed using GraphPad Prism software 6.0. Statistical significance was established at the $\mathrm{p}<0.05$ level.

\section{Results}

Between March 2012 and March 2015, 259 subjects were evaluated (Figure 1). From a database of 237 patients with diabetes, 64 were selected for study. The healthy population was derived from the blood donors' database at the hospital; 22 were invited, of which, 20 were selected. Of the 64 selected patients with DM, 40 completed the study.

In SS1, 60 patients with DM2 were studied and compared with 20 healthy controls. The mean age between the groups was statistically different ( $\mathrm{p}=$ 0.028 ). The mean age in the DM2 group was 59.52 years (SD, 9.03) and that in the healthy group was 53.10 years (SD, 11.67). There was no statistical difference between genders, with both groups containing 75\% women: 45 and 15 in the diabetic and in the healthy group, respectively. In the DM2 group, 9 patients (15\%) showed a functional deficit of a restrictive nature in spirometry, which was confirmed by a mild reduction in TLC. Eight patients (13.33\%) presented a functional deficit of mild obstructive nature without bronchodilator response. The 20 control subjects had pulmonary function test results within the set limits. The BMI was different between control and DM2 groups, respectively $27.46( \pm 4.86)$ and $30.62(5.36)(\mathrm{p}=0.022)$. The data from the evaluation of lung volume and diffusion 


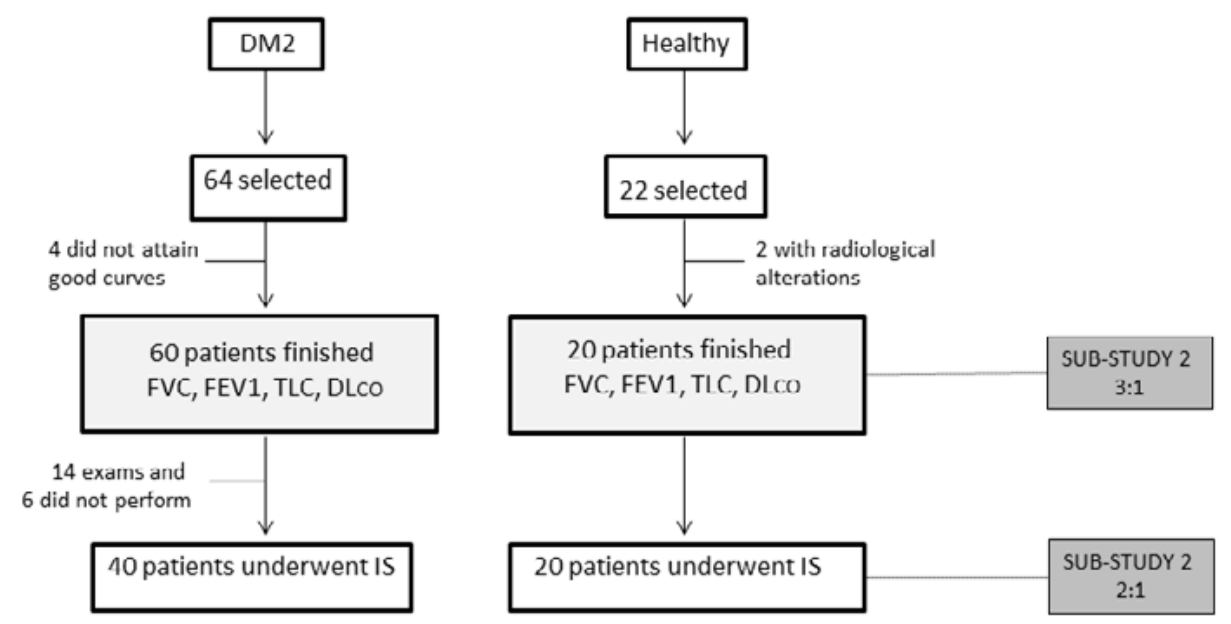

Figure 1. This protocol had two sequential studies and two arms: one arm with DM2 and other with healthy people. Sub-study 1 was to measure lung function test and sub-study 2 was to count cells and albumin

are shown in Table 1. Comparing the DM2 group with the control group, $28.33 \%$ had an obstructive or restrictive ventilatory disorder $(p=0.026$, chi-square test). The $\mathrm{DL}_{\mathrm{CO}}$ showed no significant difference $(\mathrm{p}=$ 0.193). However, final interpretation of $\mathrm{DL}_{\mathrm{CO}}$ was that they were altered in 17 patients (28.33\%). And, when taking into consideration the diagnosis below $80 \%$ of predicted, the results were different $(\mathrm{p}=0.026$, chisquared test) (Table 1 ).

In SS2, 40 patients with DM2, with an average age of 59.60 years (SD, 9.58), participated, 29 of which were women (72.5\%). The ratio of women was lower in this group, although not statistically significantly different when compared with the control group.

The lymphocyte cell count was statistically higher in the DM2 group than in the control group (Figure 2). The eosinophil, neutrophil and macrophage counts showed no statistically significant difference between the two groups (Table 2).

The airway albumin level obtained by sputum induction was $320.6 \mathrm{ng} / \mathrm{ml}$ (SD, 334.3) in the DM2 group and $217.4 \mathrm{ng} / \mathrm{mL}$ (SD, 157.9) in the control group, with no statistically significant difference $(p=0.239)$.

In the sub-studies, a difference between the healthy population and theDM2 population was observed. Both cellularity and pulmonary function were altered in the patients, an indication of pulmonary impairment, or the presence of "diabetic pneumopathy". The patients who had a change in pulmonary function and cellularity had no previous history of pulmonary

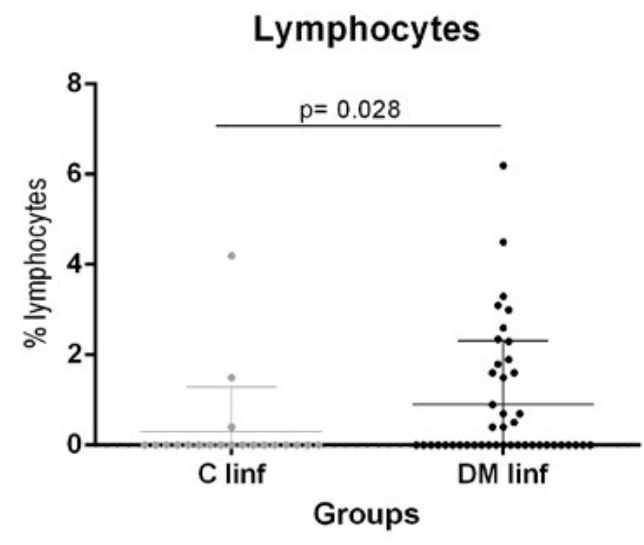

Figure 2. In healthy people, Iymphocytes were three times lower than DM2

diseases and were non-smokers. Just over a quarter of the patients had respiratory disorders, either obstructive or restrictive as diffusion capacity.

\section{Discussion}

The lung is an organ with one of the largest body surfaces. ${ }^{5}$ In this study, type 2 diabetes was affected by the abnormal finding of the largest number of lymphocyte cells in the material collected from induced sputum, demonstrating the existence of a pulmonary inflammatory process.

Some authors have reported that the restrictive pattern in patients with diabetes is associated 


\section{Original article}

Table 1. Lung function tests

\begin{tabular}{lccccc}
\hline & \multicolumn{2}{c}{ Control Group } & \multicolumn{2}{c}{ DM2 Group } & \multicolumn{2}{c}{ Statistical significance } \\
\cline { 2 - 6 } & Mean & SD $( \pm)$ & Mean & SD $( \pm)$ & 0.26 \\
\hline FVC (\%) & 99.20 & 8.67 & 95.37 & 13.21 & 0.28 \\
\hline FEV 1 (\%) & 99.45 & 9.35 & 95.35 & 13.68 & 0.86 \\
\hline FEV 1 FVC (\%) & 99.55 & 7.21 & 97.02 & 18.30 & 0.82 \\
\hline TLC (\%) & 92.20 & 11.37 & 90.92 & 12.7 & 0.26 \\
\hline $\mathrm{DL}$ (\%) $(\%)$ & 102.2 & 15.82 & 94.75 & 19.87 & 0.59 \\
\hline $\mathrm{DL}_{\mathrm{CO}} / \mathrm{V}_{\mathrm{A}}(\%)$ & 108.20 & 13.98 & 105.30 & 21.49 & \\
\hline
\end{tabular}

Legend: FVC, forced vital capacity; $F E V_{1}$, forced expiratory volume in $1^{\text {st }}$ second; TLC, Total Lung Capacity; DLCO, diffusion capacity for carbon monoxide; VA, alveolar volume; SD, standard deviation. There was no statistical difference (ANOVA).

Table 2. Differential cell count in induced sputum

\begin{tabular}{lccccc}
\hline & \multicolumn{2}{c}{ Control Group } & \multicolumn{2}{c}{ DM2 Group } & \multicolumn{2}{c}{ Statistical significance } \\
\cline { 2 - 6 } & Mean & SD $( \pm)$ & Mean & SD $( \pm)$ & P \\
\hline Lymphocytes & 0.30 & 0.98 & 0.89 & 1.42 & 0.02 \\
Eosinophils & 0.66 & 1.30 & 1.34 & 3.30 & 0.45 \\
Neutrophils & 48.53 & 21.31 & 53.50 & 22.15 & 0.47 \\
Macrophages & 40.18 & 17.88 & 34.85 & 17.88 & 0.27 \\
\hline
\end{tabular}

with obesity or, perhaps, with polyneuropathy ${ }^{13-15}$. Autonomic neuropathy, including paresis of the phrenic nerve, can affect up to $30 \%$ of the diabetic population, and obesity can reduce the functional residual capacity (FRC) ${ }^{16}$. These two mechanisms together could reduce pulmonary volumes. A metaanalysis of 40 independent studies, involving a total of 3,182 diabetic patients without pulmonary comorbidities compared with 27,080 healthy controls, showed that diabetes is associated with a restrictive functional respiratory pattern of pulmonary function ${ }^{17}$. These data were independent of body mass index (BMI), smoking, diabetes duration and the levels of glycated hemoglobin. So, restrictive patterns can occur in patients with DM2 and may be multifactorial. Our study population had a high BMI, similar to the type 2 DM group.

Metabolic syndrome is frequently found in patients with $\mathrm{COPD}^{18}$. An obstructive pattern in spirometry has been increasingly reported in non- smokers $^{19}$. Environmental or occupational pollution, vitamin $\mathrm{C}$ and $\mathrm{D}$ deficiency ${ }^{20}$, and the use of fixed values in the $\mathrm{FEV}_{1} / \mathrm{FVC}$ ratio (<0.7) for the diagnosis of COPD, rather than the limits outlined for younger people, are the reasons for increases in the diagnosis of obstructive disease among non-smokers. Nonetheless, the association is extremely frequent among nonsmokers and diabetics with COPD (OR 2.13, $\mathrm{p}<0.001)^{21}$. The patients in our study had no prior history of smoking or of respiratory atopy that could explain the airway obstruction observed in 8 of the 60 diabetic patients. It is interesting to note that this obstruction was not reversible with bronchodilator use in any patient.

The $\mathrm{DL}_{\mathrm{CO}}$ was altered in some of the patients in our study. In spite of the number of patients being a limiting factor in this study, another relevant factor is that there are different reference equations for $\mathrm{DL}_{\mathrm{Co}}$ used in the world. It is accepted that diabetic pneumopathy occurs along with nephropathy and retinopathy, with angiopathy in the pulmonary 
microvasculature, and with changes in the alveolar basal lamina ${ }^{22}$. A post-mortem histopathological study showed a thickening of the alveolar epithelium and the capillary basal lamina in patients with diabetes $^{23}$. Some studies associate dysglicemia ${ }^{24}$ and microalbuminuria ${ }^{25}$ with the reduction of $\mathrm{DL}_{\mathrm{CO}}$ in DM2. Another case-control study showed that the decrease in $\mathrm{DL}_{\mathrm{CO}}$ is an independent factor in type 2 diabetics $^{26}$. Being broader, our study tried to verify whether small changes in $\mathrm{DL}_{\mathrm{CO}}$, found only in a few studies in the literature ${ }^{27,28}$, are related to an increase in the albumin level measured in the sputum of patients with DM2. No similar studies exist in the literature. The observed low pulmonary albumin levels in the airways and the high diffusion capacity may be caused by a reduction in microvascular disease, since the patients were being managed and under DM2 monitoring. Further studies should employ techniques for improved collection of samples, such as bronchoalveolar lavage and periods of glucose decompensation.

The presence of lymphocytes in the IS has been described in several conditions, such as sarcoidosis, nonspecific interstitial pneumonia, hypersensitivity pneumonia, pneumonitis induced by drugs, vascular collagen diseases, irradiation pneumonitis, organizing cryptogenic pneumonia, and lymphoproliferative diseases $^{29}$. This is the first study to report an increase in the number of lymphocytes in patients with DM2 using sputum induction. The presence of lymphocytes in the airways signals a cellular inflammatory pathway that may be associated with a higher frequency of infections in patients with diabetes, such as tuberculosis and fungal infections ${ }^{30}$. In addition, COPD is a disease with a pluricellular model, with lymphocytosis (lymphocytic subtype CD8+) in the airways ${ }^{29}$. Our study detected some diabetic patients with limited airflow.

Our study has some limitations, such as the number of patients, the difference in age between the patients and the healthy controls, and the drop in the number of patients who finished SS2. Despite these limitations, our results can serve as a starting point for future clinical trials to assess the impact of diabetes treatment in induced sputum and lung function.

Diabetes mellitus is a chronic and debilitating disease that affects many organs, including the lungs. The presence of restrictive or obstructive ventilatory patterns associated with pulmonary lymphocytosis supports the theory of diabetic pneumopathy.

The change in pulmonary cell profile in type 2 DM with lymphocytic inflammatory characteristics associated with the presence of pulmonary ventilatory disorders reveals the reasons for the higher risk of patients with pulmonary infections and pulmonary fibrosis.

\section{Sponsorship}

Fundação de Amparo à Pesquisa do Estado do Rio de Janeiro - Faperj.

\section{References}

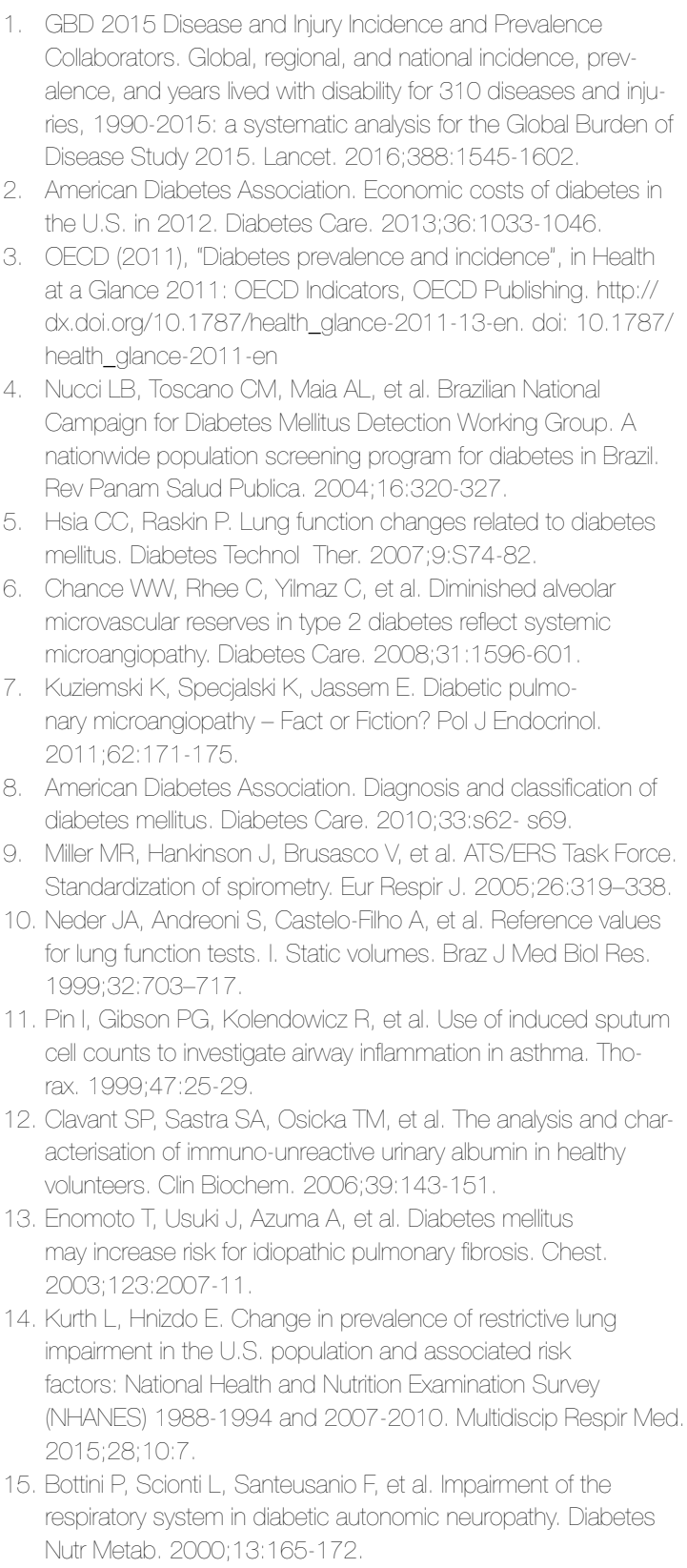




\section{Original article}

16. Langeron $O$, Birenbaum $A$, Le Saché F, et al. Airway management in obese patient. Minerva Anestesiol. 2014;80:382-392.

17. van der Borst B, Gosker HR, Zeegers MP, et al. Pulmonary function in diabetes. A meta-analysis. Chest. 2010;138:393 406. doi: 10.1378/chest.09-2622

18. Hanson C, Rutten EP, Wouters EF, et al. Influence of diet and obesity on COPD development and outcomes. Int J Chron Obstruct Pulmon Dis. 2014;5; $723-733$

19. Davis WA, Knuiman M, Kendall P, et al; Fremantle Diabetes Study. Fremantle Diabetes Study. Glycemic exposure is as. sociated with reduced pulmonary function in type 2 diabetes Diabetes Care. 2004;27:525-757

20. Tsiligianni $\mathrm{G}$, van der Molen T. A systematic review of the role of vitamin insufficiencies and supplementation in COPD. Respir Res. 2010;6:171

21. Hersh CP, Make BJ, Lynch DA, et al. COPDGene and ECLPSE Investigators. Non-emphysematous chronic obstructive pulmonary disease is associated with diabetes mellitus. BMC Pulm Med. 2014;24;14:164.

22. Marvisi M, Bartolini L, del Borrello P, et al. Pulmonary function in non-insulin-dependent diabetes mellitus. Respiration. 2001; 68: 268-272

23. Vracko R, Thorning D, Huang TW. Basal lamina of alveolar epithelial and capillaries. Quantitative changes with aging and diabetes mellitus. Am Rev Respir Dis. 1979;120:973-983

24. Agarwal AS, Fuladi AB, Mishra G, et al. Spirometry and diffusion studies in patients with type-2 diabetes mellitus and their association with microvascular complications. Indian J Chest Dis Allied Sci. 2010;52:213-216

25. Saler T, Cakmak G, Saglam ZA, et al. The assessment pulmonary diffusing capacity in diabetes mellitus with regard to microallouminuria. Inter Med. 2009;48:1939-1943.

26. Klein OL, Jones M, Lee J, et al. Reduced lung diffusion capacity in type 2 diabetes is independent of heart failure. Diabetes Res Clin Pract. 2012;96:e73-75

27. Guvener N, Tutuncu NB, Akcay S, et al. Alveolar gas exchange in patients with type 2 diabetes mellitus. Endocr J. 2003;50(6):663-667.

28. Anandhalakshmi S, Manikandan S, Ganeshkumar P. Alveolar gas exchange and pulmonary functions in patients with type 2 diabetes mellitus. J Clin Diagn Res. 2013; 7:1874-1877

29. Meyer KC, Raghu G, Baughman RP, et al. American Thoracic Society Committee on BAL in Interstitial Lung Disease. An official American Thoracic Society clinical practice guideline The clinical utility of bronchoalveolar lavage cellular analysis in interstitial lung disease. Am J Respir Crit Care Med. 2012:185:1004-1014 